\title{
Common Perceptions of the Interests of Employers, Workers, and the Government to Prevent Mass Layoffs During the Covid-19 Pandemic
}

\author{
Ahmad Hunaeni Zulkarnaen \\ Postgraduate Masters in Law, Universitas Suryakancana
}

\begin{abstract}
Since the outbreak of the first case of the Covid-19 coronavirus infection in early March 2020 to break the chain of spread, the government has taken a policy by limiting community activities that have an impact on economic and business training to reduce losses, business actors have made efficiency, among others by laying off workers or Even carrying out mass layoffs of employment, the role of all parties concerned in HI (employers, workers, or government) is needed to prevent or reduce mass layoffs and employers to reduce losses can still carry out efficiency. This study aims to analyze the shared perceptions of employers, workers, and the government to prevent mass layoffs in Indonesia. The method used in this research is a descriptive analysis using a normative juridical approach. This study concludes that in the perspective of interests, each party has different interests, namely the interests of employers to make efficiency to reduce losses, the interests of workers do not occur mass layoffs, the presence of Collective Labor Agreement (PKB) among them is to integrate and coordinate these different interests. So as not or to minimize the conflict between interests. for this reason, PKB must protect the interests of all parties in HI by limiting the interests of the parties in HI, namely, on the one hand, the PKB must safeguard the interests of employers in carrying out efficiency to reduce losses, on the other hand, PKB must protect the interests of workers, so that mass layoffs do not occur. Employers to make efficiency can only be done by limiting or reducing the interests of workers 'rights both in terms of labour legislation and terms of employment, and PKB also limits employers' interests to reduce workers' rights, namely reducing the rights of these workers. This can only be done as long as the entrepreneur has suffered losses for 3 (three) consecutive years as evidenced by a financial audit from a public accountant, the government's interest, in this case, the institution responsible for the human resources sector for strength in the legality aspect, can ratify the PKB. Therefore, from a systems perspective, all parties with interest in HI have a very close attachment and synergize with one another in harmonizing the implementation of HI (industrial peace) in the end during the Covid-19 pandemic through PKB can create a shared perception between the interests of entrepreneurs, workers and government.
\end{abstract}

Keywords: Covid-19, PKB, Common Perceptions, Interests of Employers, Workers, Government, National Economic Growth.

\section{Introduction}

Indonesia confirmed the first case of the coronavirus infection that caused Covid-19 in early March 2020. Since then, the government has made various countermeasures to reduce the impact of the Covid-19 pandemic in multiple sectors. Almost all sectors are affected, not only by health. The economic sector has also suffered severe consequences due to the coronavirus pandemic. Restrictions on community activities affect business activities, which then impact the economy (Inayah \& Surisman, 2020). The Central Statistics Agency (BPS) for August 2020 stated that Indonesia's economic growth in the second quarter of 2020 was minus 5.32 per cent. Previously, in the first quarter of 2020, BPS reported that Indonesia's economic growth only grew by 2.97 per cent, down considerably from 5.02 per cent in the same period in 2019. This weakening financial performance also had an impact on the labour situation in Indonesia. The SMERU Research Institute, an independent institution that conducts research and general studies, in August 2020 released their policy note entitled "Anticipating the Potential Impact of Crisis Due to the COVID-19 


\section{Ahmad Hunaeni Zulkarnaen et. al/ Common Perceptions of the Interests of Employers, Workers, and the Government to Prevent Mass Layoffs During the Covid-19 Pandemic}

Pandemic on the Labor Sector". On that note, the SMERU research team underlined that there are at least two implications of the economic crisis that Indonesia is experiencing in the labour sector. First, an increase in the number of unemployed, and secondly, changes in the post-crisis labour market landscape, hampered economic activity automatically causes business actors to make efficiency to reduce losses. As a result, many workers are laid off or even laid off (layoffs). Based on data from the Ministry of Manpower as of April 7, 2020, due to the Covid-19 pandemic, 39,977 companies in the formal sector chose to lay off their workers and lay off their workers. In total, there are 1,010,579 workers affected by this. In detail, 873,090 workers from 17,224 companies were laid off, while 137,489 workers were laid off from 22,753 companies (Anwar, 2020).

The domino effect of the COVID-19 pandemic on the labour sector, as described above, according to Disemadi \& Shaleh (2020), will cause backwardness in the community in the economic sector. Here there is something that is an obstacle in the form of a vicious circle of poverty. This is the leading cause of severe shortages and limitations in capital and skills income, lack of capital for investment due to low public savings. Low income reflects the low productivity of society. Low productivity is the result of a lack of money. As a result of the lack of capital for investment, it causes difficulty in economic growth efforts due to restrictions on community activities in an attempt to tackle the COVID-19 pandemic, which then affects business activities and has an impact on the economy, among others resulting in a lack of low purchasing power due to common income investment limitations. This is in line with the opinion of Subandi (2016) that investment limitations are also influenced by the lack of low purchasing power caused by low income due to insufficient community income, which is based on a report from BPS this August (2020) which states that Indonesia's economic growth in the second quarter 2020 minus 5.32 per cent. Previously, in the first quarter of 2020, BPS reported that Indonesia's economic growth only grew by 2.97 per cent, a significant decline from the development of 5.02 per cent in the same period in 2019 and one of the causes of reduced or minus economic growth in Indonesia was due to reduced capital accumulation..

\section{Method}

The approach used in this research is normative juridical, which is to study and study legal principles, especially positive legal principles derived from existing literature from statutory regulations and provisions, especially relating to the COVID-19 pandemic. Equating the perception of entrepreneurs' interests in making efficiency in efforts to overcome losses with the interests of workers to prevent or reduce mass layoffs, the government's interest is to increase national economic growth. This research also includes efforts to find concrete laws that aim to find appropriate rules and applied to a problem, especially in the study (Soemitro, 1990).

This research is a descriptive-analytical study, which provides a comprehensive and systematic overview of the correlation of PKB as a means of equating the shared perceptions between the interests of employers, workers, and government. The general picture is analyzed by starting from the statutory regulations, which aim to find and get answers to the main problems that will be discussed further. To obtain data that support this research, the data source is obtained through library research, namely by collecting and studying secondary data related to PKB correlation to equate the shared perceptions between the interests of employers and those of workers.

\section{Results And Discussions \\ Economic Growth of the Efforts of All Components of the Nation}

As explained above, capital accumulation will occur if a part of current income is saved and then invested in increasing output in the future. This type of investment is often classified as investment in the productive sector (Directly Productive Activities), namely, factories, machinery, equipment, and new goods that will increase the capital stock. Besides that, there is a human investment that aims to improve humans' quality (workers) who have a significant influence on production. These human investments are traditional schools, vocational schools, job training programs, and other informal education (Subandi, 2016).

Prajnaparamitha \& Ghoni (2020) argue, the method for overcoming the conditions of underdevelopment mentioned above, especially in the economic field, planning development as a rational alternative, in this 


\section{Ahmad Hunaeni Zulkarnaen et. al/ Common Perceptions of the Interests of Employers, Workers, and the Government to Prevent Mass Layoffs During the Covid-19 Pandemic}

case, what is essential is conscious handling of the complexity of the problems faced by planning or no, are interconnected and mutually supportive. An increase in the education sector, for example, can affect the level of productivity of society in the economic sector. Through planning, underdevelopment conditions, and the community's problems, efforts are made to systematically address the growth and development in line with the aspirations that grow in the community concerned. This is in line with the opinion of Abdul Manan (2014). However, Indonesia's economic development must be carried out by including the community's role, especially business people. Indonesian economic growth must be carried out by having part of the community. This can be seen in Article 33 paragraph (4) of the 1945 Constitution, which reads: "The national economy is carried out based on economic democracy with the principles of togetherness, efficiency, justice, sustainability, environmental awareness, independence, and by maintaining the balance of progress and national economic unity".

Likewise, Law Number 25 of 2004 concerning the National Development Planning System (Law 25/2004) clearly states that the national development system in Indonesia is an effort carried out by all Indonesian nation components to achieve the goals of the state (Randi, 2020). As stated in Article 33, paragraph (4) of the 1945 Constitution, the meaning of the principle of togetherness must be seen in the broader scope (Hendrastomo, 2010). The community (employers and workers) must realize that the government has limited funds and power to carry out economic development because development itself is very complex, so it is hoped that the mutual content of government and society (employers and workers) can be created for the success of national development (Tuwu, 2020). The principle of togetherness contained in Article 33 paragraph (4) of the 1945 Constitution places the responsibility for national expansion on the government and the community's shoulders.

In line with the thoughts of the experts stated above, Sodang Siagian in Abdul Manan (2014), that national development has the following meanings: 1) Development is a process, is a series of activities that sustainably take place and consists of stages on the one hand Independent, but on the other hand is part of something never-ending; 2) Development is an effort that is consciously determined as something to be implemented; 3) Development is carried out in a planned manner, both in the long term, medium-term and short term; 4) Planning means taking decisions now about things that will be done at a specific time in the future. The development plan implies growth and change; 5) Development leads to modernity, modernity to be achieved through various development activities as per definition is multidimensional. This means that modernity includes the life of the nation and state, which can manifest in politics, economy, socio-culture, and defence and security.

According to Kusumaatmadja (2002), the essence of national development lies in the problem of renewing ways of thinking and attitudes of life, meaning that it is necessary to change the mental attitude of all Indonesian people to anticipate national development because national product always contains new things

". The essence of the product (national, economic, employment, and HI) is a renewal of thinking and attitudes of life. It is necessary to change all Indonesian people's mental attitude to anticipate the essence of development that has been described above because of the importance of development, including the development of HI during the COVID-19 Pandemic, so to anticipate and overcome them, it is necessary to renew the way of thinking and attitude to life, it is essential to change the mental attitude of all parties interested in HI, namely patterns of thinking and life attitudes, changes in the mental attitude of belonging (sense of belonging), togetherness, mutual support, synergize to maintain business continuity and work.

\section{Development of Industrial Relations and Mutual Interest}

The correlation of labour development during the COVID-19 pandemic is following the thoughts of the experts described above, which is that employee development must be carried out by including the roles of all parties who are directly or indirectly involved in human resources development (employers, workers, government, and society) based on economic democracy with the principles of togetherness, efficiency, justice, sustainability, environmental insight, independence, and by maintaining the balance of progress and national economic unity, to realize the goals of national development, namely, in the framework of developing the whole Indonesian human being and the development of the Indonesian society as a whole, creating a prosperous, just, successful, and even community, both materially and spiritually based on 


\section{Ahmad Hunaeni Zulkarnaen et. al/ Common Perceptions of the Interests of Employers, Workers, and the Government to Prevent Mass Layoffs During the Covid-19 Pandemic}

Pancasila and the 1945 Constitution (Muhyiddin, 2020). In the implementation of national development, the workforce has a significant role and position as actors and objectives of the action, that following the part and function of the crew, it is necessary to develop a workforce to improve the quality of the force and their participation in development and to increase the protection of workers and their families following human dignity (letters a, b, c, considerations of Law Number 13 of 2003 concerning Manpower). Human resources development is to improve the workforce's quality, which, according to Juaningsih (2020), is a human investment aimed at improving people's quality (workers) who significantly influence production. These human investments are traditional schools, vocational schools, job training programs, and other informal education, which companies, governments, and communities implement.

The principle of togetherness in human resources development or human investment must be seen in a broader scope, meaning that all parties involved in human resources development or human investment must realize that the government has limited funds and resources to carry out human resources development investment. (human investment), The story of human resources or human investment itself is very complex, so that its success is expected to create complementary content from all parties with interest in it. The principle of togetherness contained in Article 33 paragraph (4) of the 1945 Constitution places the responsibility for human resources development or human investment not only on the shoulders of the government but with all parties who have an interest in it (Al-Fatih, Ahsany, \& Alamsyah (2020).

Industrial Relations Development (HI) is one of the sub-systems of human resources development or human investment and human resources development or human investment. HI, development requires all parties interested in HI (employers, workers and government). This is in line with the opinion of Ropidin \& Riyanto (2020). HI is formed between actors in producing goods or services consisting of entrepreneurs, workers/labourers and the government. Of course, the three aspects significantly affect HI's implementation from a systems perspective and in an interesting view. From a systems perspective, each party has a very close bond. Therefore, each other must be in synergy well, because if not, it will interfere with other systems in the harmonization of the implementation of HI (industrial peace: author), if only the role of the government has been appropriately implemented, the role of employers and workers must also support well. From an exciting perspective, of course, each party has different interests. The presence of HI arrangements include integrating and coordinating the interests of all parties in HI so that they do not collide with one another, in such a way that HI arrangements must be able to integrate and coordinate the interests of all parties so that the collisions between these interests can be suppressed as little as possible.

Organizing these interests is carried out by limiting and protecting the interests of all parties in HI. Indeed, in the traffic of goods in HI, protection of the parts of other parties in HI can only be done by limiting the interests of different parties. For example, as described above, during the COVID-19 pandemic, the government restricted community activities that affected business activities and impacted the economy. It also impacts the labour sector automatically, making business actors carry out efficiency to reduce losses (Kennedy, 2020). As a result, many workers are dismissed or even dismissed (PHK), this is where the importance of HI arrangements to integrate and coordinate the interests of all parties in HI, namely the interests of employers to make efficiency to reduce losses must endeavour in such a way so that they do not collide with the interests of workers who do not want layoffs to occur. Considering that workers in the process of producing goods and services are a resource and an asset that can be separated from efforts to ensure business continuity (Syafrida, Safrizal, \& Suryani (2020). Therefore, the existing work relationship needs to be maintained. Continuously in an atmosphere of industrial relations that is harmonious, dynamic, just and dignified (Vide Circular of the Minister of Manpower and Transmigration Number: SE-907 / MEN / PHI-PPHI / X / 2004 concerning Prevention of Mass Layoffs) means that through HI regulation, efficiency is companies do to suppress losses by not laying off employees so that the collision between the interests of employers and those of workers can be minimized. Protection of the interests of all parties in HI can only be carried out by limiting the interests of other parties in HI, protection of the parts of employers to make efficiency to reduce losses can only be done by restricting or reducing the interests of labour rights in the aspects of labour legislation or The terms of employment aspect, on the other hand, reduce the rights of workers from the two elements above, can only be done if based on the results of the financial audit from the company's public accountant for 3 (three) consecutive years of loss (Mardiansyah, 2020). 


\section{Ahmad Hunaeni Zulkarnaen et. al/ Common Perceptions of the Interests of Employers, Workers, and the Government to Prevent Mass Layoffs During the Covid-19 Pandemic}

This is in line with Utami (2017); the presence of law in society includes integrating and coordinating the interests that can collide with one another by law which is incorporated so that collisions can be minimized. Organizing these interests is done by limiting these interests. Indeed, in the traffic of parts, the protection of particular goods can only be done by modifying other parties' interests.

The HI Arrangement objective protects the interests of all parties in HI (employers and workers) by allocating power to all parties in HI to act in the framework of these interests. This allocation of power is carried out in a measured manner, in the sense that its breadth and depth are determined. Such power is referred to as the right of employers and labourers. This is in line with Rahardjo's (2000) legal opinion, and the law protects a person's interests by allocating power to him to act in his interests. This allocation of power is carried out in a measured manner, in the sense that the administration and its depth are determined. Such power is called right.

They are measuring the flexibility and depth of allocating power in the context of the interests of all parties in HI, apart from the rights as well as regarding the obligations of all parties in HI. Zaini (2017) calls it the term working conditions, both in labour legislation and terms of employment. The period operating conditions, namely: The level of engagement seen from the regulation of rights and obligations between labourers and entrepreneurs or company leaders. Working conditions can be divided into two broad lines, namely labour legislation and terms of employment.

Work norms (labour legislation) are the arrangements for workers' rights and obligations and employers/company directors as stipulated in statutory regulations. Therefore, the principle is imperative that must be implemented because it is mandatory; it binds all companies to be macro minimal. Macro in the sense of securing the company without exception in terms of location, size, type of business, nature of the legal entity, etc. and at least in the sense that in practice, matters that are regulated can be carried out better depending on the ability and willingness of the individual company. ".

Examples of labour legislation are: 1) Entrepreneurs are prohibited from paying the laborers' wages less than the city or regency minimum wages (Vide Article 88 paragraph (3) letter a of the UUK); 2) Entrepreneurs can only terminate labourers after obtaining a determination from the Industrial Relations Dispute Settlement Institution, abbreviated as LPPHI (Vide Article 151 paragraph (3) UUK); 3) Entrepreneurs who employ workers/labourers on official holidays are obliged to pay overtime wages (Vide Article 85 paragraph (3) UUK).

Terms of employment (terms of engagement) are the Regulation of rights and obligations for labourers and employers or company leaders regarding various aspects of work relations that have not been regulated or are not regulated by statutory regulations (work norms). This arrangement is micro conditional. Micro in the sense that it is controlled only for specific companies individually, dependent in the sense that the structure is adjusted to the conditions or capabilities of the company concerned". Examples of terms of employment are 1) Costs of Umrah pilgrimage or pilgrimage for labourers; 2) Worker's uniform; 3) Annual tours of workers and their families; 4) Worker's monthly or annual bonus if the company gets monthly or yearly profits; 5) the thirteenth salary; 6) Implementing the Circular of the Minister of Manpower and Transmigration Number: SE-907 / MEN / PHI-PPHI / X / 2004 concerning Prevention of Mass Layoffs, including a) Reducing wages and facilities for upper-level workers, for example, the level of managers and directors; b) Reducing shifts; c) Limiting / eliminating overtime work; d) Reducing working hours; e) Reducing the working day; f) dismiss or lay off workers temporarily; g) Not or to extend the contract for workers whose contract has expired; h) Providing pensions for those who have met the requirements.

As explained above, protection of the interests of other parties in HI can only be done by limiting the interests of different parties, meaning that apart from the company having an interest in reducing losses for the sake of business continuity, labourers have an interest in not laying off workers, these two interests This can be done by reducing the rights of labour both in terms of labour legislation and terms of employment.

Limiting the interests of workers in the aspect of work norms (labour legislation), for example, as long as the company experiences a loss, labourers are willing to have their wages paid in full or work more than the working hours stipulated in the labour legislation without having to be paid overtime wages. Reducing labourers' rights in terms of operating conditions (duration of employment), for example, delaying companies to pay for Umrah pilgrimages or going on hajj for workers/labourers, delaying labourers' uniform 


\section{Ahmad Hunaeni Zulkarnaen et. al/ Common Perceptions of the Interests of Employers, Workers, and the Government to Prevent Mass Layoffs During the Covid-19 Pandemic}

changes, delaying annual tours for labourers and their families, reducing their 13th salary (thirteen) implement the Circular of the Minister of Manpower and Transmigration Number: SE-907 / MEN / PHIPPHI / X / 2004 concerning Prevention of Mass Layoffs.

Limiting the interests of workers as described above must be accompanied by limiting the interests of the company, namely the entrepreneur must prove to the labourer that the company has suffered a loss for 3 (three) consecutive years, the loss of the company must be confirmed based on the results of a financial audit from a public accountant and As good as the results of the financial audit are the reasons for employers to make efficiency by reducing labourers' rights in the aspects of labour legislation and terms of employment as described above, this efficiency aims to prevent layoffs, meaning even though the company experiences losses, entrepreneurs with all their efforts must prevent layoffs (Vide Article 151 paragraphs (1 to 3) of the UUK), dismissals can only be carried out in a forced state, is the last resort after various efforts have been made, namely all parties interested in HI (especially entrepreneurs) at all costs a must try to prevent layoffs from occurring. Suppose all efforts have been made, but dismissal cannot be avoided. In that case, the entrepreneur must negotiate clearance with the labour union or labourers if the labourer is not a trade/labour union member. Suppose the negotiation does not result in an agreement. In that case, the entrepreneur can only terminate the employee after obtaining a determination from the Industrial Relations Dispute Settlement Institute (LPPHI) as regulated in Law Number 2 of 2004 concerning Settlement of Industrial Relations Disputes (UU PPHI), as long as During the negotiation regarding the plan or layoffs process at LPPHI, the entrepreneur can lay off the labourer by paying a waiting fee, the amount of the waiting money must be based on the prevailing laws and regulations or based on the results of collective bargaining between the employer and the labourer who is sent home. The limitation of entrepreneurs who house labourers is that entrepreneurs continue to pay wages in total, namely basic salaries and fixed allowances. In contrast, the labourer is laid off unless otherwise stipulated in the Work Agreement (PK), Company Regulation (PP) or Collective Bargaining Agreement (KKB) or Collective Labor Agreement (PKB). Suppose the entrepreneur is going to pay the labourers' wages not in full. In that case, it should be negotiated with the labourers' union or labourers regarding the amount of salary for being sent home and the length of time they are sent home (Vide number 1 and 2 of the Circular of the Minister of Manpower of the Republic of Indonesia Number SE- 05 / M / BW / 1998 the Year 1998 Regarding Wages of Workers Who Are Home Not to the Direction of Layoffs), if the negotiations do not reach an agreement, it must be resolved following the PPHI Law.

The government's interest in harmonizing the implementation of HI, of course, is not only limited to increasing foreign exchange and growing investment but also creating (at least maintaining: writer) jobs (which existed during the Covid-19 Pandemic) and national stability. It is in the interests of employers to ensure a conducive business climate to create business peace and increase company profits (at least maintaining the company so that it does not close during the COVID-19 Pandemic), while the interests of workers are continuity of work and increased welfare or at least during the COVID-19 Pandemic, workers are still there work or even get income to meet basic needs (clothing, shelter and food).

Referring to Sodang Siagian's opinion on the meaning of national development as described above, his correlation with the development of HI during the COVID-19 Pandemic has the following purposes:

a. HI development is a process, in the form of a series of activities in the field of working conditions that sustainably take place and consists of stages of work norms (labour legislation) to terms of employment, each of which is independent, a series of activities in the field of conditions. work (working conditions), namely increasing productivity or profits that correlate with the welfare of labourers and their families is part of something never-ending;

b. HI development in the field of working conditions by increasing productivity or profits that correlate with the welfare of labourers and their families is an effort that is consciously determined as something that must be carried out sustainably;

c. HI development in the field of working conditions (working conditions) by increasing productivity or profits that correlate with the welfare of labourers and their families must be carried out in a planned manner, both in the long term, medium term, and short term according to the ability and willingness of each. Each company; 


\section{Ahmad Hunaeni Zulkarnaen et. al/ Common Perceptions of the Interests of Employers, Workers, and the Government to Prevent Mass Layoffs During the Covid-19 Pandemic}

d. Planning means taking decisions now in working conditions for things that will be done at a specific time in the future to achieve better working conditions for all parties interested in HI (employers and labourers). Government and society). The HI development plan contains the meaning of growth and changes in the field of working conditions to minimize as little as possible the collision of the interests of all parties in HI as described above;

e. The development of HI in the field of working conditions leads to modernity. Modernity to be achieved through various HI development activities as per definition is multidimensional. This means that the modernity of HI Development in the field of working conditions includes the life of the nation and the state, HI development in a lot of working conditions must be embodied in the interests of all parties in HI, namely the welfare of all parties in HI (productivity or profits. which correlates with the welfare of labourers and their families).

Human resources development (HI during the COVID-19 Pandemic is an effort carried out by all components of labour (government, employers, workers) to achieve the objectives of labour law, the objectives of human resources development goals Article 4 letter, are: 1) empowering and empowering labourers optimally and humanely; 2) realizing equal employment opportunities and provision of human resources following the needs of national and regional development; 3 ) protect labourers in learning welfare; and 4) improving the welfare of labourers and their families.

According to Zulaichah (2019), the objectives of labour law are 1) To achieve/implement social justice in the labour sector; 2) To protect workers (workers) against the unlimited power of entrepreneurs. Number 1 more shows that labour law must maintain order and security and justice for parties involved in the production process (employers and workers) to achieve peace of work and business continuity (especially during the Covid-19 Pandemic). Point 2 is motivated by the background. There is the experience so far that often abuses employers against workers. For this reason, comprehensive and concrete legal protection from the government is needed, namely providing complete and substantial legal protection from the government from the arbitrary actions of employers against workers' rights which are labour norms on the grounds of the COVID-19 Pandemic.

Referring to the opinion of Zulaichah (2019) as described above, during the Covid 19 pandemic, the goal of employment was to achieve peace of work and business continuity by minimizing the collision between the interests of employers and those of labourers, meaning that during the COVID-19 Pandemic, companies to suppress the loss of entrepreneurs can still carry out efficiency but by not laying off labourers as described above.

According to Zulaichah (2019), labour law is also to protect employers; the existence of juridical labour laws is also intended to maintain a balance of work relations between labourers and employers so that they are always harmonious in maintaining work peace and business continuity (especially during the COVID-19 Pandemic) as well as improving the welfare (claiming a decent income) of labourers and their families (industrial peace), namely to prevent losses, companies can still make efficiency by not laying off workers and workers can always be decent and humane producers.

The essence of labour development or HI during the COVID-19 Pandemic as it is today lies in the problem of renewing or adjusting the way of thinking and life-span of all parties with interest in employment or HI, meaning that it is necessary to change the mental attitude of all parties with interest in employment or HI to anticipate labour development or HI during or after the COVID-19 Pandemic because labour development or HI during or after the COVID-19 Pandemic contains new or unexpected things.

As Kusumaatmadja (2002) argues, the essence of national development lies in renewing ways of thinking and attitudes of life, meaning that it is necessary to change all Indonesian people's mental attitude to anticipate national development because national development always contains new things. The way of thinking and attitude to life is a change in the mental attitude of all parties with interest in HI development, especially in the field of work conditions, both in terms of labour legislation and terms of employment, because during the Covid-19 pandemic, development HI, especially in the area of work conditions, contains new things, among others, the income of labour which is an aspect of labour legislation which has initially been macro-minimal to maintain the sustainability of the company and in order not to have mass layoffs it may change its nature to conditions, for example during the COVID-19 pandemic, labourers were willing to 


\section{Ahmad Hunaeni Zulkarnaen et. al/ Common Perceptions of the Interests of Employers, Workers, and the Government to Prevent Mass Layoffs During the Covid-19 Pandemic}

pay less than what they should have been paid as stipulated in the labour laws (work norms) as described above, even so, the reduction in wages for labourers must still be paid. Pay attention to income that meets pe a decent life for the humanity of labourers and their families (Vide Article 88 paragraph (1) UUK), and this is following the foundation of human resources development based on Pancasila and the 1945 Constitution of the Republic of Indonesia / UUD 1945 (Vide Article 2UUK), namely implemented in the framework of developing Indonesian people as a whole. Therefore, HI development is carried out to create prosperous, just, successful. Equitable Indonesian people and society, both material and spiritual (Vide Explanation of Article 2 of the UUK), considering that $\mathrm{HI}$ is one of the employment sub-systems. Therefore HI development must be based on Pancasila with the ultimate welfare goal for all parties (employers, workers or labourers).

The ultimate goal of HI arrangements is to increase welfare for all parties. To achieve this, it is necessary to increase productivity from time to time. Productivity can be achieved when there is peace of work and effort in the company. It is essential to communicate effectively and sustainably consciously. Communication plays a critical role in building and increasing mutual trust. All parties need mutual trust with interest in HI during the COVID-19 pandemic, namely companies with an interest in efficiency to reduce losses for the sake of business continuity; also, labourers have an interest in not laying off workers. These two interests can be done by lowering labourers, both in terms of labour legislation and terms of employment, through $\mathrm{PKB}$ as a means of HI. It can be used to foster and increase mutual trust between the two interests as described above, namely, labour believes that the interests of entrepreneurs in carrying out efficiency will not cause mass layoffs to occur to create peace of work and business in the company. Mutual trust between the parties with interest in HI will be realized if the parties implement HI based on Pancasila and PKB is one of the means to carry out HI Pancasila.

\section{Pancasila Industrial Relations and Collective Labor Agreement}

Pancasila Industrial Relations (HIP) is a system of relationships formed between the actors in the production process of goods and services (workers, employers and the government), which is based on values that manifest the prevailing principles of Pancasila and the Basic Law, which grows and develops on the national personality and national culture of Indonesia (Asikin, 2016). According to Asikin (2016), the HIP is HI which is imbued with the five principles of Pancasila, which read: 1) A labour relationship that recognizes and believes in work as human service to God and fellow humans; 2) Workers are not just a factor of production but as individuals with all their dignity and dignity; 3) Labor relations that lead to Indonesian unity, do not differentiate between class, belief, politics, ideology, sect, religion, ethnicity, gender; 4) Labor relations based on the principle of deliberation and consensus, eliminating differences, seeking similarities towards an agreement between workers and employers; 5) A labour relationship that encourages the creation of social justice for all Indonesian people; therefore the results of economic development must be shared in a harmonious, balanced and equitable manner.

One of the means of the HIP is the PKB or the term used in Law Number 13 of 2003 concerning Employment (UUK), is a Collective Labor Agreement (PKB) in English known as the Collective Labor Agreement (CLA) or in Dutch, it is called Collective Arbeids Overemkoms (CAO), this agreement is known in the realm of Indonesian law based on the provisions of the Civil Code. PKB is an agreement resulting from negotiations between a trade union/labour union or several trade unions/labour unions registered at the agency responsible for human resources affairs and an entrepreneur or several entrepreneurs which contains the working conditions, the rights and obligations of both parties (Vide Article 1 paragraph (21) UUK)".

During the COVID-19 Pandemic, the PKB content was responsive both to the interests of employers and the interests of workers, namely the interests of employers to make efficiency by reducing workers' rights both in the aspects of labour legislation and terms of employment and the interests of labour efficiency is carried out. The entrepreneur does not result in or reduce the occurrence of mass layoffs as described above, because the CLA can be made by one trade union or several trade unions that have been registered with the agency responsible for human resources affairs with an entrepreneur or several employers (Vide Article 116 UUK), bearing in mind that The PKB-making process involves trade unions and employers, in addition to containing elements of participation from the employer or several employers, as well as from the workers, 


\section{Ahmad Hunaeni Zulkarnaen et. al/ Common Perceptions of the Interests of Employers, Workers, and the Government to Prevent Mass Layoffs During the Covid-19 Pandemic}

the strategy for making PKB is responsive, that is, a significant role in its making is not only given to employers or other parties. Several employers but also with substantial participation from all workers (Prameswari \& Handayani, 2018). So that the PKB is following HI, which is imbued with the principles of Pancasila as described above, namely: A PKB that recognizes and believes in work as human devotion to God and fellow humans, PKB which views labourers not only as a production factor but as a personal person with all its dignity and dignity, $\mathrm{PKB}$ as a means of encouragement towards the unity or togetherness of all parties with interest in HI (employers, workers and government), PKB whose manufacturing process is based on the principle of deliberation-consensus, eliminating differences, seeking similarities towards an agreement between labourers and employers, PKB which encourages the creation of social justice for all parties interested in HI, for that the results of company productivity/profits must be shared in a harmonious, balanced and equitable manner by all parties interested in HI, as well as losses a company can be felt too old workers, so that in HI, the relationship between employers and workers is a partnership relationship, namely partners in the production process, partners in the profits and losses of the company.

Likewise, in the opinion of Einstein, Helmi, \& Ramzy (2020), to make a PKB, a worker union is needed as a worker representative. The CLA is made through negotiations between employers and trade unions so that the PKB process contains elements of worker participation. This participation is also a way to Together with estimating and determining the fate of the company and the future, PKB should not discuss the work conditions related to the company's requirement for the past before the Covid 19 pandemic, because before the COVID-19 pandemic, there were no restrictions on community activities affecting business activities, it is better if PKB discusses work conditions related to the current situation of the company, namely during the Covid-19 pandemic and at the time after the Covid-19 pandemic, the present time is during the Covid-19 pandemic, namely how companies carry out the efficiency by reducing workers' rights both in the aspect of norms work (labour legislation) nor the terms of employment (term employment) do not result in or reduce the occurrence of mass layoffs or the efficiency imposed by employers or laborers will still get decent and humane income, in the future after the Covid-19 pandemic and the company's financial condition will improve, how can companies restore laborers' rights that have been reduced during the COVID-19 pandemic as described above, so that mutual trust grows between all parties interested in HI and mutual trust will be realized if there is good faith in the process and implementation of the PKB.

\section{Collective Labor Agreement and Good Faith Principle}

The process of making it must contain elements of participation of workers and employers; PKB is a collective work agreement which, in its implementation, the role of good faith (te goeder trouw) has a significant meaning, that good faith is the most critical joint in the PKB and must be implemented in good faith or honesty, both in good faith during the process of making it and implementing the work norms (labour legislation) and the terms of employment that have been regulated in the PKB. This is in line with Hulima (2017); the role of good faith (te goeder trouw) has a significant meaning; good faith is the most crucial element in contract law. Article 1338 paragraph (3) of the Civil Code states that: "The agreement must be carried out in good faith". Good faith, which is referred to in Dutch as te goeder trouw, which is often also translated honestly, can be divided into 2 (two) types, namely: (1) Good faith at the time of agreeing; and (2) Good faith when exercising the rights and obligations arising from the agreement.

Good faith at the time will make PKB nothing but an estimate in the heart of all parties with a direct interest in HI (especially employers) that the reduction of work conditions during the Covid-19 pandemic is in the form of aspects of work norms (labour legislation) and work requirements. (term of employment) is a very forced condition, namely to reduce company losses for the sake of business continuity for entrepreneurs and job continuity for labourers, as well as legally valid or the process of making PKB following the Regulation of the Minister of Manpower of the Republic of Indonesia Number 28 of 2014 concerning Procedures How to Create and Ratify Company Regulations and Create and Register Collective Bargaining Agreements. As for goodwill, when implementing rights and obligations (work norms and working conditions) arising from a CLA also lies in the heart of the entrepreneur. However, in implementing the PKB, workers must heed decency and justice standards by keeping away. Of actions that may cause harm to other parties, be it the employer or the employee. 


\section{Ahmad Hunaeni Zulkarnaen et. al/ Common Perceptions of the Interests of Employers, Workers, and the Government to Prevent Mass Layoffs During the Covid-19 Pandemic}

CLA, which reduces workers' rights both in terms of labour legislation and terms of employment as long as the company suffers a loss due to the impact of the COVID-19 pandemic carried out in good faith or not, will be reflected in the natural actions of employers. The labourer implements the PKB so that even though the good faith in implementing the PKB lies in the entrepreneur's inner heart, the worker is subjective. Still, this good faith can also be measured objectively. In contrast to most of the writers of Indonesian legal experts who always considered good faith to be subjective, among the Dutch legal experts, among others, Hofmann and Volmaar believed that in addition to the emotional understanding of goodwill in the implementation of the PKB, there was also objective goodwill that was referred to as decency (billikheid redelijkheid) to implement the agreed $\mathrm{PKB}$.

An agreement is carried out in good faith or not, will be reflected in the natural actions of the person carrying out the contract, so that even though the goodwill in the implementation of the agreement lies in the human heart, which is subjective, but that good faith can also be measured objectively. In contrast to most of the writers of Indonesian legal experts who always considered good faith to be subjective, the Dutch jurists, among others, Hofmann and Volmaar, believed that in addition to the subjective notion of good faith, there was also objective goodwill called appropriateness (billikheid redelijkheid).

The principle of good faith applies in the process of making and implementing PKB as well as contained in Article 14 paragraph (2) of the Regulation of the Minister of Manpower of the Republic of Indonesia Number 28 of 2014 concerning Procedures for Making and Ratifying Company Regulations and Making and Registering Collective Labor Agreements / Permenaker RI Number 28 of 2014, which regulates the PKB negotiations must be based on good faith and the free will of both parties.

\section{Conclusion}

Restrictions on community activities as a result of the COVID-19 pandemic affect business activities, and obstruction of economic activity automatically makes business actors carry out efficiency to reduce losses; as a result, many workers have been dismissed or even laid off (layoffs) to overcome this in HI development, the role of the three HI elements, namely elements of entrepreneurs, aspects of labourers and parts of government, these three elements certainly greatly influence the implementation of HI both from a systems perspective and an interesting perspective. In a systems perspective, each party has a very close attachment; therefore, each other must be well synergized, because if not, it will interfere with other systems in the harmonization of the implementation of HI (industrial peace), If only the role of the government has been carried out properly, the functions of employers and labour must also be well supported.

From the perspective of interests, of course, each element has different interests. The presence of HI arrangements includes integrating, coordinating and equating the perceptions of the interests of all parties in HI so that the collision between these interests can be minimized as little as possible. Organizing between interests by limiting and protecting all parties' interests in HI, the interests of entrepreneurs to carry out efficiency to reduce losses must have endeavoured in such a way so that they do not collide with the interests of labourers who do not want layoffs to occur. Protection of interests in HI can only be done by limiting the interests of other parties in HI, protecting the interests of employers in carrying out efficiency to reduce losses can only be done by restricting or reducing the interests of labour rights both in terms of work norms (labour legislation) and terms of employment, on the other hand, reduce the rights of labourers from the two aspects above, can only be carried out if based on the results of a financial audit from a public accountant, the company for 3 (three) consecutive years has suffered losses or as long as the company suffers a loss. Protection and restrictions between interests must be stated in the PKB, which is one of the HI facilities that is imbued with the principles of Pancasila and the strategy for making it is responsive both to the interests of employers and the interests of labour, of course, all parties interested in HI (employers and labourers) must implementing PKB in good faith (te goeder trouw) so that in the company there will be peace in business and at work (industrial peace) to increase company productivity correlated with the welfare of labourers and their families, which is one of the main assets to boost Indonesia's economic growth.

\section{References}


Ahmad Hunaeni Zulkarnaen et. al/ Common Perceptions of the Interests of Employers, Workers, and the Government to Prevent Mass Layoffs During the Covid-19 Pandemic

1. Al-Fatih, S., Ahsany, F., \& Alamsyah, A. F. (2020). LEGAL PROTECTION OF LABOR RIGHTS DURING THE CORONAVIRUS DISEASE 2019 (COVID-19) PANDEMIC. Jurnal Pembaharuan Hukum, 7(2), 100- 115. https://doi.org/10.26532/jph.v7i2. 10975

2. Anwar, M. (2020). Dilema PHK dan Potong Gaji Pekerja Di Tengah Covid-19. 'Adalah : Buletin Hukum \& Keadilan, 4(1), 173- 178. https://doi.org/10.15408/adalah.v4 i1.15752

3. Asikin, Z. (2016). Dasar-Dasar Hukum Perburuhan. Jakarta: Raja Grafindo Persada.

4. Disemadi, H. S., \& Shaleh, A. I. (2020). Banking credit restructuring policy amid COVID-19 pandemic in Indonesia. Jurnal Inovasi Ekonomi, 3(3). https://doi.org/https://doi.org/10.2 2219/jiko.v5i3.11790

5. Einstein, T., Helmi, M. I., \& Ramzy, A. (2020). Kedudukan Peraturan Pemerintah Pengganti Undang-Undang Nomor 1 Tahun 2020 Terkait Covid-19 Perspektif Ilmu Perundang-Undangan. SALAM: Jurnal Sosial Dan Budaya Syar-I, 7(7), 595-612. https://doi.org/10.15408/sjsbs.v7i7 .15826

6. Hendrastomo, G. (2010). Menakar Kesejahteraan Buruh: Memperjuangkan Kesejahteraan Buruh diantara Kepentingan Negara dan Korporasi. Informasi, 36(2), 1-17. https://doi.org/10.21831/informasi .v2i2.6205

7. Hulima, D. I. (2017). Perlindungan Hukum Bagi Tenaga Kerja Tidak Mendapatkan Pesangon oleh Perusahaan Menurut Undang-Undang Nomor 13 Tahun 2003. Lex Privatum, 5(6).

8. Inayah, \& Surisman. (2020). Work Termination During The Covid-19 Pandemic in The Perspective of Positive Law in Indonesia. Legal Standing: Jurnal Ilmu Hukum, 4(1), 247-254.

9. Juaningsih, I. N. (2020). Analisis Kebijakan PHK Bagi Para Pekerja Pada Masa Pandemi Covid-19 di Indonesia. 'Adalah: Buletin Hukum \& Keadilan, 4(1), 189- 196. https://doi.org/10.15408/adalah.v4 i1.15764

10. Kennedy, R. (2020). Legal Discourse on Manpower During COVID-19 Outbreak. Law Reform, 16(1), 70- 86. https://doi.org/doi.org/10.14710/lr. v16i1.30306

11. Kusumaatmadja, M. (2002). Konsep-Konsep Hukum dalam Pembangunan, Bandung: Alumni.

12. Manan, A. (2014). Peran Hukum Dalam Pembangunan Ekonomi. Jakarta: Prenadamedia Group.

13. Mardiansyah, D. (2020). The Corona Virus and Labor Rights Issues: How Do Workers Get Their Rights? The Indonesian Journal of International Clinical Legal Education, 2(2), 129-146. https://doi.org/doi.org/10.15294/iji cle.v2i2.38328

14. Muhyiddin. (2020). Covid-19, New Normal, dan Perencanaan Pembangunan di Indonesia. Jurnal Perencanaan Pembangunan: The Indonesian Journal of Development Planning, 4(2), 240- 252. https://doi.org/10.36574/jpp.v4i2. 118

15. Prajnaparamitha, K., \& Ghoni, M. R. (2020). Perlindungan Status Kerja Dan Pengupahan Tenaga Kerja Dalam Situasi Pandemi COVID-19 Berdasarkan Perspektif Pembaharuan Hukum. Administrative Law \& Governance Journal, 3(2).

16. Prameswari, K., \& Handayani, E. M. I. P. (2018). Pengaturan Pemutusan Hubungan Kerja Antara Karyawan Dengan Perusahaan. Mizan: Jurnal Ilmu Hukum, 8(1), 99-112. https://doi.org/10.32503/mizan.v7i 1.923

17. Randi, Y. (2020). Pandemi Corona Sebagai Alasan Pemutusan Hubungan Kerja Pekerja Oleh Perusahaan Dikaitkan Dengan Undang-Undang Ketenagakerjaan. Yurispruden: Jurnal Fakultas Hukum Universitas Islam Malang, 3(2). 
Ahmad Hunaeni Zulkarnaen et. al/ Common Perceptions of the Interests of Employers, Workers, and the Government to Prevent Mass Layoffs During the Covid-19 Pandemic

18. Ropidin, \& Riyanto, S. (2020). DAMPAK PEMUTUSAN HUBUNGAN KERJA PADA PERUSAHAAN FARMASI TERKAIT COVID-19 DI INDONESIA. Jurnal Syntax Transformation, 1(5), 167-174. https://doi.org/10.46799/jurnal\%2 0syntax\%20transformation.v1i5.6

19. Soemitro, R. H. (1990). Metodologi Penelitian Hukum Dan Jurimetri, Jakarta: Ghalia Indonesia.

20. Subandi. (2016). Ekonomi Pembangunan. Bandung: Alfabeta.

21. Syafrida, Safrizal, \& Suryani, R. (2020). PEMUTUSAN HUBUNGAN KERJA MASA PANDEMI COVID- 19 PERUSAHAAN TERANCAM DAPAT DIPAILITKAN. Pamulang Law Review, 3(1), 19- 30. https://doi.org/dx.doi.org/10.3249 3/palrev.v3i1.6532

22. Tuwu, D. (2020). KEBIJAKAN PEMERINTAH DALAM PENANGANAN PANDEMI COVID-19. Journal Publicuho, 3(2), 267-278. https://doi.org/10.35817/jpu.v3i2. 12535

23. Utami, T. K. (2015). Peran Serikat Pekerja Dalam Penyelesaian Perselisihan Pemutusan Hubungan Kerja. Jurnal Wawasan Yuridika, 28(1).

24. Zaini, A. (2017). Pengaturan Pemutusan Hubungan Kerja (PHK) Menurut Peraturan Perundanganundangan Ketenagakerjaan. Al-Ahkam, 13(1).

25. Zulkarnaen, A. H. (2017). Penyuluhan Tentang Tata Cara Membuat Peraturan Perusahaan Di PT. Pelangi Warna Kreasi Bandung. Journal of Empowerment, 1(1).

26. Zulaichah, S. (2019). Pemutusan Hubungan Kerja Sepihak Ditinjau dari Hukum Ketenagakerjaan dan Hukum Islam. Journal of Islamic Business Law, 3(4), 1-12. Retrieved from http://urj.uinmalang.ac.id/index.php/jibl/article /view/424 